\title{
Sanitation of Lightly Processed Fruits and Vegetables
}

\author{
William C. Hurst \\ Department of Food Science and Technology, The University of Georgia, Athens, GA 30602
}

\section{SANITATION LINKED TO SHELF LIFE AND SAFETY}

What is the importance of sanitation to the lightly processed fruit and vegetable industry? To a processor its value is difficult to measure because sanitation is not directly reflected on the (profit and loss) statement. Unlike affixing a price to a piece of equipment designed to deliver $\mathrm{x}$ units of product per hour, sanitation's economic value cannot be readily pinpointed in accounting terms. Thus, some processors do not invest the resources necessary to ensure good sanitation in their processing plant. Yet, research has demonstrated that an increase in microbial populations on lightly processed produce (LPP) (i.e., shredded lettuce) will have a direct impact on shelf life. The higher the initial microbial load, the shorter the storage life (Bolin et al., 1977). While psychrotrophic gram-negative rods are the predominant microorganisms on LPP (Neelima et al., 1990), the primary spoilage organism on prepackaged salads appears to be a fluorescent pectinolytic pseudomonad, Pseudomonas marginalis (Nguyen and Prunier, 1989). [Note: More information concerning the bacteria cited in this paper can be found in Bergey's Manual (Krieg and Holt, 1984)].

So what should be the goal of processors wanting microbial reduction and shelf life extension of LPP? They should institute and maintain consistent sanitary practices via chlorinated washes (Adams et al., 1989) and uniform refrigeration management (Bolin et al., 1977; Gertmenian, 1992). Shelf life, however, is not the critical sanitation issue in the lightly processed fruit and vegetable industry. It is product safety. To ensure product acceptance, safety is the single greatest challenge for this industry. But, the same technology developed to extend the shelf life of LPP, namely modified-atmosphere (MA) packaging, may inadvertently lead to a product that is potentially more hazardous to consume. How can this be true?

\section{WHAT ARE THE SAFETY RISKS?}

I perceive five major bacteriological risks of LPP. 1) Although refrigeration is used to maintain quality, it provides inadequate protection against pathogenic microorganisms because no kill step, i.e., blanching, is used before storage. Several bacterial pathogens can survive and even reproduce under refrigerated conditions. 2) While MA storage inhibits the growth rate of many spoilage organisms, certain pathogens, i.e., Listeria monocytogenes, may actually thrive under these conditions (Berrang et al., 1989). 3) When the product is at $7 \mathrm{C}$ or above during storage, distribution, or both, the growth of other bacterial pathogens, i.e., Clostridium botulinum, Bacillus, Salmonella spp., and Staphylococcus aureus, will occur (Corlett, 1989). 4) Partial processing operations, i.e., trimming and washing, may not only eliminate the presence of normal indigenous spoilage organisms, but also give any introduced pathogens a competitive advantage for growth. 5) Finally, unlike canned or frozen fruits and vegetables, LPP is consumed raw.

\section{PATHOGENS OF CONCERN AND THEIR SOURCE}

Which bacterial pathogens most recently implicated in human foodborne disease are of most concern in LPP and where do they originate (Table 1)? In addition, other pathogens not considered a serious problem today, but which may pose a potential threat for LPP, have been reviewed (Brackett et al., 1993). Bacterial pathogens may often contaminate produce when poor field sanitation, packinghouse, and shipping practices are employed (Brackett, 1992; Hurst, 1992). Since animal feces is a good source of these pathogens, cropland should not be used for grazing livestock. Likewise, inorganic fertiliz- 
Table 1. Some bacterial foodborne diseases associated with fruits and vegetables. ${ }^{2}$

\begin{tabular}{|c|c|c|c|}
\hline Disease & Bacterial cause & $\begin{array}{c}\text { Outbreak } \\
\text { date }\end{array}$ & Commodity \\
\hline Gastroenteritis & $\begin{array}{l}\text { Staphylococcus aureus } \\
\quad \text { (documented enterotoxir }\end{array}$ & $\begin{array}{l}1989 \\
n)\end{array}$ & $\begin{array}{l}\text { Imported, canned } \\
\text { mushrooms }\end{array}$ \\
\hline Shigellosis & $\begin{array}{l}\text { Shigella sonnei } \\
\quad \text { (documented) }\end{array}$ & 1983, 1989 & Shredded lettuce \\
\hline Listeriosis & Listeria monocytogenes & 1981 & Coleslaw \\
\hline \multicolumn{4}{|l|}{ Traveler's } \\
\hline diarrhea & $\begin{array}{l}\text { Enterotoxigenic } \\
\text { Escherichia coli }\end{array}$ & 1974 & $\begin{array}{l}\text { Salad vegetables, } \\
\text { consumed raw }\end{array}$ \\
\hline \multirow[t]{2}{*}{ Botulism } & $\begin{array}{l}\text { Clostridium botulinum } \\
\text { (suspected) }\end{array}$ & 1987 & $\begin{array}{l}\text { Coleslaw (modified- } \\
\text { atmosphere-packaged) }\end{array}$ \\
\hline & $\begin{array}{l}\text { Clostridium botulinum } \\
\text { (documented) }\end{array}$ & 1985,1989 & $\begin{array}{l}\text { Chopped garlic } \\
\text { in oil }\end{array}$ \\
\hline \multirow[t]{3}{*}{ Salmonellosis } & $\begin{array}{l}\text { Salmonella javiana } \\
\quad \text { (suspected) }\end{array}$ & 1990 & $\begin{array}{l}\text { Sliced/whole raw } \\
\text { tomatoes }\end{array}$ \\
\hline & $\begin{array}{l}\text { Salmonella chester } \\
\quad \text { (suspected) }\end{array}$ & 1989-90 & $\begin{array}{l}\text { Cut and served } \\
\text { muskmelon }\end{array}$ \\
\hline & $\begin{array}{l}\text { Salmonella poona } \\
\quad \text { (suspected) }\end{array}$ & 1991 & $\begin{array}{r}\text { Salad-bar cut } \\
\text { muskmelon }\end{array}$ \\
\hline
\end{tabular}

${ }^{2}$ Adapted from Hurst (1993).

ers are preferred to organic fertilizers. Produce growers operating near animal farms must monitor their ground water supplies to ensure freedom from pathogens. Packing produce in the field may lead to contamination because of poor personal hygiene among workers, inadequate sanitary facilities, or both. Cleanable, plastic containers or bins should be used for harvested produce because they can be sanitized regularly.

Sanitation practices must improve at most packinghouse operations. Many, but not all, packinghouses use chlorination to keep the wash water, as well as manufactured ice, sanitized. Two targeted areas for improvement would be to routinely clean the packinghouse equipment/facility with detergent and sanitize it, and mandatory employee training regarding good personal hygiene. Since fresh produce is not protected from the environment during distribution, truck-trailers should be cleaned before loading to prevent pathogenic crosscontamination. It is not uncommon for the same trailer to be used for shipping live poultry to the western United States and then backhauling bin lettuce to the east, without cleaning the trailer between trips.

\section{INHERENT FACTORS INFLUENCING SAFETY}

\section{Processing}

Circumstances exist in the typical processing plant that put lightly processed produce at great bacteriological risk. It is well-established that the outer surfaces of many whole vegetables are contaminated with pathogenic bacteria (Silliker et al., 1988). Vegetables are then systematically dismantled at the processor by cutting, chopping, and slicing. Cutting releases nutrient-laden juices from tissues, which encourages faster growth and higher populations of microorganisms on both the product and processing equipment (Brackett et al., 1993). Additional human handling during the washing, drying, and packaging operations increases the risk for pathogen contamination. Although processing occurs in a cold room (5-10C) and products are washed in refrigerated water (1-2C), these temperatures do not preclude the growth of certain pathogens, i.e., Listeria monocytogenes and some strains of Escherichia coli, which are psychrotrophic (Palumbo, 1987).

\section{Employee practices}

In terms of safety, one of the greatest potential sources of bacterial pathogen transfer to LPP are the employees who physically handle products during their preparation. Food handlers are vectors of disease transmission if they are carriers of the pathogen and practice poor personal hygiene. Salmonellae (Pether and Gilbert, 1971), shigellae (Davis et al., 1988), and Listeria spp. (Kerr et al., 1993) survive on the hands of food workers, which emphasizes the importance for thorough hand sanitizing to interrupt the transmission of these organisms to LPP.
Training personnel regarding sanitary practices is not easy because of the diverse ethnic and educational backgrounds in the work force. Difficulties arise in teaching new ideas because of cultural differences and language barriers (Hurst, 1992). Many employees previously have worked at outdoor vegetable or fruit packinghouses, where bacteriological control through proper sanitary procedures was not addressed. For these reasons, one of the biggest hurdles facing the LPP industry is changing employee attitudes and making them aware that good sanitation does make a difference by ensuring product safety. The delivery of educational training programs on plant sanitation and employee hygiene is the best mechanism to instill this awareness.

\section{Plant sanitation}

In addition to employee sanitary training, more attention should be focused on the sanitary layout of the processing facility. Processing rooms should maintain positive air pressure, that is, air flow should always be directed from the packaging area (cleanest) to the area where raw produce is received (dirtiest). This design will reduce airborne contamination of the finished products. All niches, such as cracks in walls, floors, or ceiling, must be sealed to prevent pest infiltration and eliminate the presence of bacterial reservoirs. Ideally, open floor drains with metal grates should be replaced by PVC piping sealed in concrete. This action would circumvent pathogen accumulation in these hard-to-clean areas.

Also, better sanitary design of processing equipment is needed. Much of the line equipment used in LPP plants is so specialized that it must be fabricated by maintenance personnel. Unfortunately, its design is based on functionality, not sanitary requirements. Special attention must be given to smoothing out rough welds and avoiding the inclusion of any dead spots (areas where product lodges and then falls back into the product stream) in the equipment design. These areas will entrap debris and make cleaning difficult.

In-plant chlorination is the primary form of sanitation used in the water systems of LPP plants. Most processors use a concentrated form of liquid bleach ( $12 \%$ to $15 \%$ sodium hypochlorite) instead of chlorine gas or the solid form, calcium hypochlorite. Gas is a liability because of its explosiveness, and solid granules need to be dissolved. Unfortunately, many processors measure the total chlorine concentration, rather than the concentration of free available chlorine, in their process waters. Free chlorine measurement would give a better indication of disinfection, since microbial kill is directly related to the amount of free chlorine (as hypochlorous acid) in the water (Bartz and Eckert, 1987). As little as $1 \mathrm{ppm}$ free residual chlorine will sanitize cold process waters at a $\mathrm{pH}$ 6.5-7.0 (Palin, 1983). Since water $\mathrm{pH}$ has such a significant impact on chlorine activity, it is most important that processors adjust the $\mathrm{pH}$ of their water systems when using commercial liquid bleach, which, when added, increases water $\mathrm{pH}$. Some processors use a citric acid buffer to correct water $\mathrm{pH}$ and improve chlorine efficacy, but most merely add more chlorine. Higher chlorine levels may cause product discolorations, increase equipment corrosion, and form volatile chloramines that are a health hazard because they irritate workers' lungs and skin. Additionally, improper chlorine treatments may not eliminate pathogens, i.e., Listeria monocytogenes (Brackett, 1987), or effectively reduce spoilage organisms (Beuchat and Brackett, 1990) from LPP.

\section{Achieving safety}

Tissue disruption during processing and the extra human handling involved in produce preparation provide many opportunities for pathogenic contamination. Many processors now realize that bacteriological hazards cannot be controlled by inspecting the finished product. So how will processors be able to achieve the level of sanitation necessary to ensure safety? What is needed is a preventative method of control.

This aim can best be accomplished by instituting a Hazard Analysis Critical Control Point (HACCP) inspection of LPP plants (Scott, 1993). Under the HACCP plan, emphasis is placed on safety not quality; this is how HACCP differs from a traditional quality control program. For example, HACCP would be designed to prevent the presence of bacterial pathogens in chopped lettuce, but would not 
guarantee the absence of brown leaves in a 2-kg bag of shredded lettuce. How would HACCP be developed and implemented for a company manufacturing LPP? First, one must identify all potential areas where bacterial pathogens may be introduced as produce moves from the field to the consumer. Key areas would be the field (during cultivation and harvesting), packinghouse, processing plant, and distribution chain to the consumer. Hazardous areas would be designated critical control points (CCP). This plan would consist of continuously monitoring these CCPs using appropriate documentation procedures to ensure that bacterial pathogens do not become part of the product. In a nutshell, the goal behind HACCP is to nip the hazard in the bud before it becomes a reality in the packaged product.

\section{FUTURE CONCERNS}

As demand for LPP continues to increase, there is real concern over the possible regulatory restriction of chlorine use in processing waters. Research is mounting on the formation and persistence of toxic compounds called trihalomethanes (i.e., chloroform) and their demonstrated carcinogenicity (M. Jantschke, 1992, personal communication). Loss of chlorine to an industry so heavily dependent on it will have a major impact unless a suitable alternative can be found.

A potential replacement under close review is ozone (Jantschke, 1993). Because of its strong oxidizing power, ozone more completely breaks down organic matter into low-molecular-weight, biodegradable compounds. To date, there are no indications of adverse human health or environmental effects of water ozonation. However, current Food and Drug Administration regulation only permits the use of ozonation for disinfecting drinking water systems, manufacturing bottled water, and, most recently, recycling poultry-plant chilled water.

Another technology choice would be the use of low-dose irradiation. Recent successful marketing of irradiated whole produce has renewed interest in this means of preservation (Unrein, 1993); however, research is needed on how it would affect LPP. For example, how would gamma rays affect the textural quality of mechanically damaged tissue? In terms of safety, it is important to note that irradiation does not have the same effect on all microorganisms. While gramnegative bacteria (including produce spoilers and many enteric pathogens) appear to be the most sensitive, gram-positive sporeformers (i.e., Clostridium botulinum) are more tolerant (Brackett, 1992).

Without doubt, temperature abuse of LPP during distribution and retail display is of critical concern to processors. This is the one area where processors have little control over safety. Training that demonstrates how to handle these products properly during distribution is needed for truckers and wholesalers. In addition, retail employees must be taught how to display packages properly at the correct temperature. Safeguards in the form of temperature-sensitive labels that change color if the product is temperature-abused during its display have been suggested (Cole, 1993). Maintaining proper refrigeration $(0.5-3 C)$ throughout the "cold chain"-processing through consumption - and properly educating both suppliers and consumers of lightly processed fruits and vegetables are the keys to ensuring safety of these products.

\section{Literature Cited}

Adams, M.R., A.D. Hartley, and L.J. Cox. 1989. Factors affecting the efficacy of washing procedures used in the production of prepared salads. Food Microbiol. 6:69-77.
Bartz, J.A. and J.W. Eckert. 1987. Bacterial diseases of vegetable crops after harvest, p. 351-376. In: J. Weichmann (ed.). Postharvest physiology of vegetables. Marcel Dekker, New York.

Berrang, M.E., R.E. Brackett, and L.R. Beuchat. 1989. Growth of Listeria monocytogenes on fresh vegetables stored under controlled-atmosphere. J. Food Protection 54:702-705.

Beuchat, L.R. and R.E. Brackett. 1990. Survival and growth of Listeria monocytogenes on lettuce as influenced by shredding, chlorine treatment, modified atmosphere packaging and temperature. J. Food Sci. 55:755758.

Bolin, H.R., A.E. Stofford, A.D. King, Jr., and C.C. Huxsoll. 1977. Factors affecting the storage stability of shredded lettuce. J. Food Sci. 42:13191321.

Brackett, R.E. 1987. Antimicrobial effect of chlorine on Listeria monocytogenes. J. Food Protection 50:999-1003.

Brackett, R.E. 1992. Shelf stability and safety of fresh produce as influenced by sanitation and disinfection. J. Food Protection 55:808-814.

Brackett, R.E., D.M. Sundlewood, S.M. Fletcher, and D.L. Horton. 1993. Food safety: Critical points within the production and distribution system, p. 301-326. In: R.L. Shewfelt and S.E. Prussia (eds.). Postharvest handling: A systems approach. Academic, San Diego.

Cole, J. 1993. Temperature control-Helping prevent contamination. Packer 100(29):3C.

Corlett, D.A., Jr. 1989. Refrigerated foods and use of hazard analysis and critical control point principles. Food Technol. 43:91-94.

Davis, H., J.P. Taylor, J.N. Perdue, G.N. Stelma, Jr., J.M. Humphreys, Jr., R. Rowntree, III, and K.D. Greene. 1988. A shigellosis outbreak traced to commercially distributed shredded lettuce. Amer. J. Epidemiol. 128:13121321.

Gertmenian, D. 1992. Maximum shelf life is critical in fresh cut marketing. Produce Business 8(10):76-83.

Hurst, W.C. (ed.). 1992. Recommended sanitary guidelines for produce processing industry. Natl. Assn. Fresh Produce Processors, Alexandria, Va.

Hurst, W.C. (ed.). 1993. Handling guidelines for fresh-cut produce. The Packer and Vance Publishing, Lincolnshire, Ill.

Hurst, W.C. and G.A. Schuler. 1992. Fresh produce processing-An industry perspective. J. Food Protection 55:824-827.

Jantschke, M. 1993. Ozone as a potential chlorine replacement. In: National Food Processors Association Information Letter. Natl. Food Processors Assn., Washington, D.C. 3285:7.

Kerr, K.G., D. Birkenhead, K. Seale, J. Major, and P.M. Hankey. 1993. Prevalence of Listeria spp. on the hands of food workers. J. Food Protection 56:525-527.

Krieg, N.R. and J.G. Holt. (eds.). 1984. Bergey's manual of systematic bacteriology. Williams and Wilkins, Baltimore.

Neelima, G., J.J. Chivey, and D.F. Splittstoesser. 1990. Effect of processing conditions on the mucoflora of fresh-cut vegetables. J. Food Protection 534:701-703.

Nguyen, T.C. and J.P. Prunier. 1989. Involvement of pseudomonads in deterioration of 'ready-to-use' salads. Intl. J. Food Sci. Technol. 24:47-58.

Palin, A.T. 1983. Chemistry and control of modern chlorination. LaMotte Chemical Products Co., Chestertown, Md.

Palumbo, S.A. 1987. Can refrigeration keep our foods safe? Dairy Food Sanitation 7:56-60

Pether, J.V.S. and R.J. Gilbert. 1971. The survival of salmonellas on finger-tips and transfer of organisms to foods. J. Hygeine Camb. 69:673-681.

Scott, V.N. 1993. Implementation of HACCP in a food processing plant. J. Food Protection 56:548-554.

Silliker, J.H., A.C. Bard-Parker, F.L. Bryan, J.H.B. Christian, T.A. Roberts, and R.B. Tomplin (eds.). 1988. Microorganisms in foods. 4-Application of the hazard analysis critical control point (HACCP) system to insure microbiological safety and quality. Blackwell Scientific Publications, Oxford, England.

Unrein, J. 1993. Irradiated produce—Broker's sales double. Packer 100(6):10C. 